\title{
Rевевски Автіске: Responses of wilt tolerant varieties of lentil under Bundelkhand condition of Uttar Pradesh
}

\author{
R.K. Singh, V. R. Chaudhry, Ram Prakash and M.K. Singh
}

Article Chronicle: Received :

15.02.2020;

Revised:

03.10.2020;

Accepted :

$22 . .10 .2020$

\section{KeY Words :}

Autumn season, Desiccate area, Photoassimilates, Photosynthates, Pilot area
SUMMARY : The adaptive trial was laidout during Rabi season with the objective to increase the lentil production with wilt tolerant varieties and replace the old cultivars, which is in vogue. The soil of operational area is Kabar, having low fertility status. The wilt tolerant cultivars $D P L-62, K-75$ and $P L$ 406 were tested with local variety, which is popularized among the farming majority. The cultivars were planted in the first fortnight of November and harvested after 128 DAS in the second fortnight of March. The highest average yield of lentil was recorded in cultivar $D R L-62$ by $15.75 \mathrm{q} / \mathrm{ha}$, which lowest average seed yield of $13.00 \mathrm{q} /$ ha was recorded in local check, varieties $K-75$ and $P L-406$ produced grain yield by $14.75 \mathrm{q} /$ ha and $14.00 \mathrm{q} /$ ha, respectively. The yield contributing character were concordance to grain yield of lentil. The maximum BCR 1:2.36 was calculated with cultivar DPL-62 closely followed by $K-75$ (1:2.14). The minimum BCR noted under local check.

How to cite this article : Singh, R.K., Chaudhry, V.R., Prakash, Ram and Singh, M.K. (2020). Responses of wilt tolerant varieties of lentil under Bundelkhand condition of Uttar Pradesh. Agric. Update, 15(4): 359-362; DOI : 10.15740/HAS/AU/15.4/359-362. Copyright@2020: Hind Agri-Horticultural Society.
R. K. Singh

Krishi Vigyan Kendra,

Rura Mallu, Jalaun (U.P.)

India

Email: rasinghcsau@

gmail.com

See end of the article for authors' affiliations 